\title{
Study of Impact of Time Management on Academic Performance of College Students
}

\author{
Prof. Mehnaz Kaushar \\ Tikaram Jagannath College Of Arts, Commerce And Science, Khadki, Pune-03
}

\begin{abstract}
The aim of the research was to determine the relationship between the time management skills and academic achievement of students.

Because many times college students have not had to manage their time efficiently prior to college because they are bright and weren't really challenged in high school. The situation often changes in college because everyone who goes to college did well in high school but the full range of grades are assigned. Some students who received ' $A$ ' and ' $B$ ' grade in high school are now receiving ' $C$ ' and ' $D$ ' in college.

Those receiving lower grades are probably no less capable than those receiving higher grades but often their study skill, including time management are less effective.
\end{abstract}

Key words: - Management Skills, Efficiently, Time Management

\section{INTRODUCTION:-}

Now-a-days college students are spending less time in studying. The fall 2003 survey conducted by the Higher Education Research Institute at UCLA's Graduate School of Education And Information Studies found that only $34 \%$ of today's students are spending more than six hours per week outside their classes on academic related activities like completing homework, self studying etc. during their high school period.

Today college students are less prepared for college level work than their predecessors. Once they get into colleges, they tend to spend less time for studying and would like to do job, some even full time (DT Smart, C.A. Kelly \& J.S. Conant 1999)

Time management plays a vital role in improving student's academic performance. Each \& every student should have time management ability which includes setting goals $\&$ priorities, using time management mechanism (such as making "TO DO LIST") and being organized in using time.

Here time management is only possible through self motivation.

Performance $=$ Ability $*$ Motivation

For Example:-

A student with very high ability but low motivation is unlikely to perform well, whereas a student with low ability but high motivation is likely to perform well. That is the variability in motivation across students.

The basic problems or constraints related to time management are like:-

- Spending hours on social - networking sites.

- Talking too much on phone

- No proper schedule

- Working for the organization

- No proper guidance

- No goals, objectives, mission, vision or targets

- Hanging outside with friends.

These are the few activities performed by today's college students, which act as a barrier between them and their academic performance. And due to miss management of time they lag behind.

This study will help to analyze the positive or negative impact of time management on academic performance of students. It will also help to make some decision about changes we would like to make to use our time more effectively.

"There is no one right way to manage our time; however; it is important to get to know our self, so we can make good decisions about how to use our time." 


\section{OBJECTIVES OF THE STUDY}

- To analyze the positive or negative impact of time management on academic performance of students.

- To analyze how much approximate hours student spend on their academics.

- To analyze what are the problems faced by students while preparing a proper schedule.

- To analyze the role of time management in student's life.

- To identify strengths and weaknesses in students time management practices.

\section{DATA SOURCES}

\section{RESEARCH METHODOLOGY}

The data collected for the study includes both primary data and secondary data.

\section{METHODS}

The research methodology of the proposed research paper comprises the interview, questionnaire and case study method for collecting the primary data and secondary data was collected from various sources such as magazines, reference books, articles etc.

\section{SAMPLE SIZE}

50 college students.

\section{HYPOTHESIS}

There is a direct relationship between academic performance and time management.

It is commonly believed that students who spend more time on academic related activities outside of class (e.g. reading the text, completing assignments, studying and preparing reports) are better performers than those who spend less time on these activities.

Without making proper schedule or planning academic performance may get affected.

\section{LIMITATIONS OF THE STUDY}

- Research report is restricted to college students only.

- Analyzing student's psychology is very difficult.

- Most of the students do not follow any schedule and they are not aware with the time management concepts.

- It is a time consuming process.

- This paper enumerates only college students.

\section{FINDINGS AND CONCLUSION}

- The aim of this study was to determine the relationship between the time management and academic achievement of college students. As a result of this it was determined that student's behaviour in the category of time planning was at the highest level and behaviour in the category of time management was at the lowest level. The success of students was above average.

- There was a significant and positive relation between time planning, time management and academic performance of the students.

- There was a low and positive relation between time consumers and academic achievement, there was a meaningful and moderate relation between time management and academic achievement. 